\title{
A “escalada da violência" em Juiz de Fora: Para pensar melhor...
}

\section{Ellen Rodrigues ${ }^{1}$}

"[...] Precisam de olhos novos, de outras mãos, precisam de arados e sapatos, de lanternas e bandas de música, da visão do licorne e da comunidade com Jesus. [...]"?.

Os pobres, Murilo Mendes - poeta juiz-forano ${ }^{3}$

\begin{abstract}
Resumo
O presente estudo pretende refletir sobre os impactos do crescimento econômico e populacional verificado no município de Juiz de Fora nos últimos anos, tendo por objetivo contextualizar a dita "onda de violência" percebida nos anos de 2012 e 2013 e suas repercussões na sociedade. Para tanto, pretende-se analisar historicamente as consequências da falta de políticas sociais integradas para crescimento do município desde o início do século XX, de modo a perceber os reflexos decorrentes de tal processo na vida social e na segurança pública.
\end{abstract}

Palavras-chave: Urbanização; violência; políticas públicas; direitos sociais.

La escalada de la violencia en Juiz de Fora: para pensar mejor...

\section{Resumen}

Este artículo analiza los efectos del crecimiento económico y demográfico observado en el municipio de Juiz de Fora en los últimos años, con objetivo de contextualizar la llamada "ola de violencia", percibida en 2012 y 2013, y sus repercusiones en la sociedad. Para ello, se pretende analizar de forma histórica las consecuencias de la falta de políticas sociales integradas para el crecimiento del municipio desde el principio del siglo $\mathrm{XX}$, con el fin de percibir los efectos derivados de tal proceso en la vida social y en la seguridad pública.

Palabras clave: Urbanización; violencia; políticas públicas; derechos sociales.

\footnotetext{
${ }^{1}$ Professora de Direito Penal e Criminologia na UFJF; Mestre em Ciências Sociais pela UFJF; Doutoranda em Direito Penal na UERJ. E-mail: pepajf@yahoo.com.br

2 Os pobres, Murilo Mendes - poeta juiz-forano Murilo Monteiro Mendes (Juiz de Fora, 13 de maio de 1901) - Lisboa, 13 de agosto de 1975): poeta e prosador, expoente do surrealismo brasileiro.

${ }^{3}$ Murilo Monteiro Mendes (Juiz de Fora, 13 de maio de 1901 - Lisboa, 13 de agosto de 1975): poeta e prosador, expoente do surrealismo brasileiro.
} 


\section{Thoughts on the "escalation of violence" in Juiz de Fora}

\section{Abstract}

This article analyzes the impacts of the economic and population growth registered in the municipality of Juiz de Fora over recent years, with the aim of contextualizing the so-called "wave of violence" felt in 2012-2013 and its repercussions in society. To do so, it therefore conducts a historical analysis of the consequences of the lack of integrated social policies for the growth of the municipality from the beginning of the twentieth century, in order to gauge the reactions to such a process in social life and public security.

Keywords: Urbanization; violence; public policies; social rights.

\section{Pistes d'analyse de l'" escalade de la violence » à Juíz de Fora}

\section{Résumé}

Cet article analyse les impacts de la croissance économique et démographique constatée ces dernières années dans la commune de Juiz de Fora. L'objectif est de contextualiser la « vague de violence » des années 2012 et 2013 et ses répercussions sur la société. À cette fin sera réalisée une analyse historique des conséquences de la pénurie de politiques sociales intégrées pour accompagner la croissance de la ville depuis le début du $X X^{\text {ème }}$ siècle, de manière à identifier les effets de ce processus sur la vie sociale et sur la sécurité publique.

Mots-clés : Urbanisation ; violence ; politiques publiques ; droits sociaux.

\section{茹伊斯德福拉的“暴力升级”：重新思考}

摘要:

本论文分析了巴西城市茹伊斯德福拉（Juiz de Fora）最近几年经济和人口的迅速增长,

以此为背景分析 2012 年和 2013 年期间人们明显的感觉到的

“暴力潮”，及其对社会的影响。作者认为，自 20 世纪初以来一直到目前，这个城市政府一直缺乏统一的城市 规划和社会管理政策，因此产生了各种后果，这些后果直接影响到人民的社会生活和公共安全。

关键词：城市化，暴力，公共政策，社会权利。

Juiz de Fora é um município brasileiro no interior do estado de Minas Gerais. Pertencente à região da Zona da Mata, localiza-se a sudeste da capital do estado, distando desta pouco mais de $280 \mathrm{~km}$ e cerca de $180 \mathrm{~km}$ do Rio de Janeiro. Atualmente, a cidade é conhecida como polo cultural e comercial de uma região que abrange mais de dois milhões de pessoas. Em 2002, Juiz de Fora foi considerada pela edição 781 da revista EXAME um dos melhores lugares para se viver no Brasil, além de 22 a melhor cidade brasileira para negócios no ranking das 100 melhores. O município integra importante malha viária de acesso aos principais mercados consumidores e produtores brasileiros, aos potenciais fornecedores e aos principais terminais marítimos da região sudeste. 
Entre os setores mais aquecidos da economia local, destacam-se os setores de indústria, comércio e serviços ${ }^{4}$. A contribuição do setor industrial é da ordem de $34 \%$ do PIB da microrregião e advém de seu diversificado parque produtivo, o qual conta com empresas do setor automotivo, têxtil e vestuário, metalúrgico, químico e alimentar (laticínio). Entre as empresas mais representativas estão: Mercedes Benz, Belgo Mineira, White Martins, Quiral Química do Brasil, Paraibuna de Metais, Laticínios Candido Tostes. Destaca-se, ainda, o setor da construção civil, que tem grande importância na cidade ${ }^{5}$.

Além de excelentes instituições particulares de ensino, o município conta ainda com uma Universidade Federal que possui cerca de 50 opções de cursos de graduação, 32 de mestrado e 15 de doutorado, especializações, MBA, residência e educação de base, figurando como importante centro de conhecimento, cultura e geração de emprego e renda. Contemplando, ainda, o ensino profissionalizante, a cidade conta com o Instituto Federal de Educação, Ciência e Tecnologia do Sudeste Mineiro (IFET), que conta com cerca de 3500 alunos matriculados em cursos técnicos e mais de 200 nas turmas de graduação ${ }^{6}$.

Com pouco mais de 500 mil habitantes, Juiz de Fora está entre as cidades brasileiras com os melhores índices de qualidade de vida ${ }^{7}$. A cidade tem um PIB per capita de $\mathrm{R} \$ 6,2$ mil e uma das mais altas expectativas de vida do Brasil $^{8}$. Com indicadores capazes de garantir elevado padrão de qualidade de vida para muitos segmentos da população, Juiz de Fora apresentava, até os últimos 10 anos, um cotidiano livre de engarrafamentos, de poluição e com baixos índices de violência, se comparados aos das cidades de porte mais elevado. Todavia, esse quadro social vem apresentando mudanças que se relacionam ao crescimento econômico e populacional verificado na cidade nos últimos anos. Importa destacar, contudo, que tal crescimento - amplamente fomentado e incrementado pelas últimas administrações - é um traço característico da

\footnotetext{
${ }^{4}$ Disponível em: http://www.cps.ufjf.br/anuarios/Anuario2012/index.html, acessado em 23 abr. 2014.

${ }^{5}$ Chaves, T. S. (2011). "Estudo de caso - a cidade de Juiz de Fora MG - sua centralidade e problemas sócio-econômicos". In Rev. GEOMAE, Campo Mourão, v.2, n.esp.1, p.156.

${ }^{6}$ Fonte: IFET - Instituto Federal de Educação, Ciência e Tecnologia do Sudeste Mineiro; Centro de Pesquisas Sociais / Anuário 2012. Obs.: Até 2009 a instituição era ligada à UFJF - Colégio Técnico Universitário, em http://www.cps.ufjf.br/anuarios/Anuario2012/index.html, acessado em: 21 abr. 2014.

${ }^{7} \mathrm{http}: / /$ cidades.ibge.gov.br/xtras/temas.php?lang=\&codmun=313670\&idtema $=16 \&$ search $=|| s \%$ EDntese-dasinforma\%E7\%F5es, acessado em 23 abr. 2014.

${ }^{8}$ Disponível em: <http://www.pjf.mg.gov.br/cidade/>, acessado em 23 abr. 2014.
} 
cidade (a qual ficou conhecida, no início do século XX, como "Manchester Mineira") ${ }^{9}$, que, sob o signo do desenvolvimentismo, sempre foi legitimado e fomentado pelas elites locais.

Conforme Luciane Tasca, as camadas média e média-alta existentes em Juiz de Fora, formadas por pequenos empresários, comerciantes e profissionais liberais, foram as principais incentivadoras e parceiras da administração municipal no que tange às estratégias de crescimento da cidade, tanto no âmbito da industrialização, quanto na especulação imobiliária. Ao longo de seu trabalho As contradições e complementaridades nas leis urbanas de Juiz de Fora: dos planos aos projetos de intervenção ${ }^{10}$, é possível identificar a relação entre as classes médias urbanas proprietárias e os setores do capital (beneficiados pela política pública) com a especulação fundiária havida na cidade ao longo do século XX, bem como com o consequente crescimento urbano desordenado, determinante para o crescimento das áreas de periferia.

Segundo Tasca ${ }^{11}$, nos diferentes projetos de urbanização da cidade, elaborados ao longo do século $X X$, percebe-se que aqueles cuja ênfase recai no foco econômico e na infraestrutura viária foram os mais desenvolvidos, resultando em ações diretas sobre o tecido urbano. Já os voltados para a melhoria da qualidade de vida da população, tendentes à elevação dos níveis de acessibilidade à moradia e serviços urbanos para todos os cidadãos, tiveram, e ainda têm, entraves das mais diversas ordens. Disto resulta um crescimento desordenado e desigual: "de um lado os bairros favorecidos pela proximidade com os novos eixos criados, apresentando melhorias em sua estrutura; de outro os bairros que não se valeram desses projetos e continuam fazendo parte da agenda de necessidades da administração local".

Para a referida pesquisadora, as dificuldades do poder público em implementar medidas de melhoria efetiva no tecido urbano e social da cidade residem na política elitista e conservadora, cujo foco central ainda é a ligação de Juiz de Fora com uma rede

\footnotetext{
${ }^{9}$ Manchester é uma cidade do Reino Unido, no noroeste da Inglaterra. A cidade é um grande centro industrial e econômico. Manchester teve um papel primordial na Revolução Industrial, no século XIX, por isso seu nome pode ser utilizado para adjetivar algumas cidades que se destacam pelo desempenho industrial e econômico. Paula, Z. A. de (2006). E do caminho novo das Minas dos Matos Gerais emerge a 'Manchester Mineira' que se transformou num "bau de ossos": história de Juiz de Fora: da vanguarda de Minas Gerais a "industrialização periférica. Tese (Doutorado) - Programa de Pós-Graduação em História Econômica, Campinas: UNICAMP. Disponível em:<http://www.bibliotecadigital.unicamp.br/document/?code=vtls000378898>. Acesso em: 24 abr. 2014

${ }^{10}$ Tasca, L. (2010). As contradições e complementaridades nas leis urbanas de Juiz de Fora: dos planos aos projetos de intervenção. Tese (Doutorado)-Universidade Federal do Rio de Janeiro.

${ }^{11}$ Ibidem, p. 194-95.
} 
de cidades, fortalecendo os laços econômicos e enfraquecendo cada vez mais os laços com os cidadãos das classes populares ${ }^{12}$. Nesse sentido, em Juiz de Fora, a questão central no debate sobre as práticas de planejamento urbano baseia-se na falta de vontade política dos governantes, ou melhor, na busca de não entrar em conflito com os interesses privados detentores do capital, o que provocou repetidas vezes, ao longo do século XX, 0 adiamento da revisão das leis de uso do solo, parcelamento e zoneamento. "O resultado dessa ação é a afirmação da desigualdade sócio-espacial e de acesso aos serviços da cidade por algumas parcelas da população"13.

Nos últimos anos os efeitos desse processo se fizeram sentir mais plenamente em face do intenso trabalho de reorganização espacial desenvolvido na cidade ao final da década de $1990^{14}$. Em 1996, sob o promessa de reestruturação urbana e social do município foi adotado um novo Plano Diretor ${ }^{15}$. O documento é fruto de estudos interdisciplinares e intenso trabalho de pesquisa no âmbito do reconhecimento territorial e do crescimento sustentável. Mas aos olhos do historiador Rafael Almeida ${ }^{16}$, o Plano Diretor apresenta problemas graves, principalmente no que tange à ordenação do território e redução das desigualdades sociais. Almeida identifica falhas no zoneamento do município, o qual é realizado a partir do desconhecimento da formação dos bairros e de uma tentativa equivocada de se projetar a cidade com base em um macrozoneamento. Para o pesquisador, o ideal numa cidade heterogênea em termos de ocupação como Juiz de Fora é trabalhar com unidades pequenas de trabalho, preferencialmente com bairros em separado ou com bairros vizinhos sem grandes contrastes estruturais, sem desconsiderar problemas culturais diversos, como rivalidades e estigmas ${ }^{17}$.

Nesse sentido, embora fruto de estudos mais elaborados, o referido Plano Diretor, assim como os anteriores, apresenta dificuldades para a consecução dos objetivos

\footnotetext{
12 Ibidem, p. 193.

${ }^{13}$ lbidem, p. 95. em: 24 abr. 2014.

${ }^{16}$ Almeida, R. (2005). Op. Cit.

17 Ibidem, p. 7.
}

${ }^{14}$ Chaves, T. S. (2011). Op. Cit., p. 157.

${ }^{15}$ Os Planos Diretores urbanos são instrumentos que trabalham com a racionalização e regulamentação do desenvolvimento das cidades, buscando reduzir as desigualdades e dar aos segmentos marginalizados, incapazes de adquirir moradias, oportunidades adequadas de acesso às mesmas e aos demais direitos, de modo a reduzir as situações de vulnerabilidade social. Almeida, R. (2005). "Planejamento Urbano em Juiz de Fora: Reflexões Históricas". In Anais do I Colóquio de História Econômica e Social da Universidade Federal de Juiz de Fora, p. 8-10. Disponível em: <http://www.ufjf.br/lahes/files/2010/03/c1-a59.pdf>. Acesso 
propostos. Segundo Almeida ${ }^{18}$, nenhum dos planos desenvolvidos em Juiz de Fora até hoje foi realmente implementado. Numa análise mais genérica, entre os objetivos traçados pelas referidas leis urbanas verifica-se que as maiores preocupações foram: em 1844, a de se ter a planta da cidade; em 1883 a de se elaborar o cadastro de imóveis; em 1912, já se verifica a necessidade de um zoneamento como forma de separação social; em 1938 a tônica era o crescimento e a regulamentação do uso do solo; em 1986, a necessidade de um ordenamento devido ao inchaço das regiões centrais e o surgimento desenfreado de bairros populares e, em 1996 e 1998 uma busca de se enquadrar no modismo do "desenvolvimento sustentável"19.

Em 2005, por ocasião do aniversário de 155 anos da cidade, um jornal local publicou uma reportagem onde pessoas destacadas da sociedade comentavam os problemas da cidade. Ao serem questionadas sobre qual seria o "lugar mais feio da cidade?", apresentaram respostas da seguinte natureza: "as áreas onde habitam os menos favorecidos e as ruas centrais; o Centro, por todas suas desordens, do trânsito à mendicância; as áreas degradadas do Rio Paraibuna; o lugar feio da cidade é onde o poder público não planeja"20. Para Almeida ${ }^{21}$, todas estas afirmativas estão ligadas a uma só questão: a falta de planejamento urbano e ao crescimento desordenado.

As insatisfações em relação aos problemas urbanos como transporte, saúde, educação, soma-se a preocupação com o aumento da violência, com destaque para os últimos dois anos, cujos índices de crimes como homicídio e tráfico de drogas superaram as estatísticas verificadas no município nos últimos dez anos. Nesse sentido, as políticas de segurança pública passaram a ocupar lugar de destaque na agenda local. A despeito de reflexões mais profundas sobre o aumento da violência, sobretudo nas áreas de periferia e na região central, a população juiz-forana vem clamando por medidas incisivas de combate e repressão ao crime. Em meio ao clima de insegurança e pânico social, as classes médias e os representantes dos setores de serviços e comércio são os que mais vêm demonstrando sua insatisfação em face do cenário local. No entanto, como ocorrido em outros momentos da história da cidade, quando as consequências do crescimento

\footnotetext{
18 Ibidem, p. 9.

${ }^{19}$ Referências retiradas do Plano Diretor Urbano (disponível para consulta em http://www.pjf.mg.gov.br; e Ribeiro Neto, Eustácio (1999). Elaboração de um mapa esquemático (Planta-Guia) da cidade de Juiz de Fora. UFJF. Monografia de Bacharelado em Geografia apud Almeida, R. (2005). Op. Cit., p. 9.

${ }^{20}$ Jornal Panorama, 31/05/2005, p. 08-15 apud Almeida, R. (2005). Op. Cit.

${ }^{21}$ Almeida, R. (2005). Op. Cit.
} 
desordenado e da ausência de políticas públicas efetivas começam a afetar decisivamente os segmentos que sempre apoiaram os programas de crescimento e expansão populacional ${ }^{22}$, estes mesmos grupos passam a propugnar pela necessidade de reformas urbanas e incremento nas estratégias de controle social.

O presente trabalho se propõe a analisar a dita "onda de violência" percebida nos anos de 2012 e 2013, e as estratégias de enfrentamento apresentadas, não com fenômeno isolado, mas como fruto de rupturas e permanências históricas no processo de urbanização do município. Para tanto, trabalhar-se-á com o método histórico, enfocando Juiz de Fora; aspectos que normalmente são obscurecidos pelo discurso triunfalista da industrialização, que busca assinalar a singularidade da cidade como polo de desenvolvimento e símbolo de modernidade ${ }^{23}$.

Assim, para além do mito desenvolvimentista, o estudo pretende refletir, sobre os problemas decorrentes dos processos de crescimento mal instituídos e antidemocráticos da cidade, que - segundo Maria Adélia Souza ${ }^{24}$ - estão relacionados às dinâmicas decorrente dos processos de modernização do país. Tal fenômeno, sem dúvida, poderia ser estudado a partir de dados de outras cidades, a opção por Juiz de Fora, no entanto, se justifica pelo fato de que no município vislumbra-se a possibilidade de articulação entre as características de periferia, margem e fronteira, tornando extremamente rica a análise de sua tessitura social e urbana, sobretudo no que tange às relações entre crescimento urbano, segurança pública e estratégias de controles sociais das classes menos favorecidas.

\section{A "Manchester" mineira e o custo social do progresso}

Conforme estudo de Albino Esteves ${ }^{25}$, Juiz Fora utilizada como entreposto comercial, via de passagem e parada de tropeiros, a vila que surgiu do capital advindo

\footnotetext{
${ }^{22}$ Goodwin Jr., J. W. (1986). A "Princeza de Minas": a construção de uma identidade pelas elites juizforanas. 1850-1888. Dissertação de Mestrado apresentada ao Programa de Pós-graduação em História da UFMG. Belo Horizonte: FAFICH / UFMG.

${ }^{23}$ Musse, C. F. (2006). Imprensa, cultura e imaginário urbano: exercício de memória sobre os anos 60/70 em Juiz de Fora. Tese (Doutorado) - Programa de Pós-Graduação em Comunicação da Escola de Comunicação, UFRJ, p. 16.

${ }^{24}$ Souza, M. A. A. (2012), "Uso do território e sistema de justiça no Brasil". In Batista, V.M. (Org.) (2012). Loïc Wacquant e a questão penal no capitalismo neoliberal, Rio de Janeiro: Revan. p. 139.

${ }^{25}$ Esteves, Albino (2008). Álbum do Município de Juiz de Fora, Juiz de Fora: FUNALFA. Reedição da 1aㅡ Edição em 1915, por Sérgio Murilo de Almeida Neumann.
} 
das lavouras de café, ao longo do Caminho Novo, foi se tornando importante pólo industrial, correspondente ao ideal da nação idealizada pela República.

Segundo Douglas Fazolatto ${ }^{26}$, o censo populacional de 1855, aponta para uma população de 27.722 habitantes, o que significa um grande crescimento em relação ao mapa da população de 1831, que registrava apenas 1419 pessoas na localidade. Nesse período, Juiz de Fora é o centro que atrai os investimentos de uma burguesia emergente, com destaque para Mariano Procópio Ferreira Lage. Após receber concessão imperial para a construção da estrada que ligaria Juiz de Fora a Petrópolis, Mariano Procópio colocou em ação a Companhia União \& Indústria, responsável pelo crescimento da cidade, o qual foi influenciado, sobretudo, pela vinda dos imigrantes. Para além do mito do desenvolvimentismo, os imigrantes enfrentaram uma série de dificuldades para manterem-se em condições mínimas de sobrevivência. Sobre este aspecto a história de Juiz de Fora permanece obscura ${ }^{27}$.

Por outro lado, registra-se também o descontentamento de muitos setores da população local para com "certos estrangeiros" que perturbavam a tranquilidade pública. Essas queixas, como destaca Fazolatto ${ }^{28}$, eram feitas com relação àqueles que, com sua produção arruinada, abandonavam suas terras da colônia agrícola destinada aos imigrantes e partiam em direção à cidade, para juntarem-se a outros estrangeiros desempregados ou sem nenhuma atividade profissional definida.

À massa de trabalhadores e imigrantes pobres, juntaram-se ciganos, escravos, desempregados, prostitutas, crianças e adolescentes em situação de marginalização e exclusão social, os quais - acusados de ameaçarem a ordem na região - eram alvo dos mecanismos de controle social. O primeiro Código de Posturas Municipais da cidade, a qual ainda era chamada de Santo Antônio do Paraybuna, já expressava preocupações com a presença de imigrantes, negros e ciganos, as quais iam de encontro à implementação da política modernizante da elite. Goodwin Jr. dedica um capítulo de seu trabalho a análise do primeiro Códigos de Posturas da Câmara Municipal, sendo o primeiro de 1858, publicado em 1860. O autor destaca que o referido diploma funciona

\footnotetext{
${ }^{26}$ Fazolatto, D. (2001). Juiz de Fora: imagens do passado, Juiz de Fora: Funalfa, p. 16.

27 Existe um grande número de trabalhos publicados sobre o tema. Citaremos como referência as seguintes obras: Borges, Célia Maia (Org.) (2000). Solidariedades e conflitos: histórias de vidas e trajetórias de grupos em Juiz de Fora, Juiz de Fora: Ed. UFJF; Andrade, Sílvia M. B. Vilela de (1987). Classe operária em Juiz de Fora: uma história de lutas (1912-1924), Juiz de Fora: Ed. da UFJF; Dutra, Elione F. (1998). Caminhos operários nas Minas Gerais, São Paulo: Hucitec.

${ }^{28}$ Fazollato, D. (2001). Op. Cit., p. 29.
} 
como um instrumento de controle social e afirmação da hegemonia da elite da cidade, posto que, apesar de pretender regulamentar a vida urbana com igualdade de leis para todos, acaba por reforçar as desigualdades ${ }^{29}$.

Entre os principais alvos das medidas de ordem e controle social estavam os negros, sobretudo os cativos urbanos. Conforme destaca o historiador Caio Silva Batista, em sua obra $A$ opinião pública e os escravos em um núcleo urbano da Zona da Mata mineira, Juiz de Fora 1870 - 1888, as décadas de 1870 - 1880 apresentam relevância por representarem o período de auge do sistema escravista no núcleo urbano de Santo Antônio do Paraibuna. O censo realizado em 1872 que demonstra o município detentor de $26 \%$ da população escrava da província de Minas Gerais. Para reconstruir o cotidiano dos cativos urbanos, o autor utilizou os conjuntos documentais dos processos criminais que estão no inventário do Fórum Benjamim Colluci do período imperial, estes documentos somam num total de mil oitocentos e noventa e três processos. Com base na imprensa da época, o historiador analisou as relações sociais de solidariedade e conflito entre os cativos urbanos, os demais escravos e a população livre. Estas interações, que estão presentes em noticiários e anúncios do jornal $O$ Pharol, relatam as badernas, os batuques, as fugas, os crimes, as brigas e outras agitações sociais que os escravos, individualmente ou em grupo, promoviam dentro do núcleo urbano, nas fazendas e nos distritos de Juiz de Fora ${ }^{30}$.

Em relação aos crimes cometidos pelos escravos urbanos juiz-foranos na segunda metade do século XIX, Caio Batista destaca que os furtos e roubos eram comuns. O autor registra inclusive furtos de alimentos por parte de escravos famintos. Segundo Caio, nem sempre os escravos cometiam crimes sozinhos, em alguns momentos, se juntavam em bandos para conseguirem cometer algum delito, o que ensejava pânico generalizado às elites urbanas, que exigiam providências enérgicas por parte das autoridades, sobretudo quanto à perturbação do sossego ${ }^{31}$.

A notícia de prisão de negros cativos no centro urbano de Juiz de Fora ocorreu em maior incidência nos oito últimos anos da escravidão. Esta maior incidência de prisões

\footnotetext{
${ }^{29}$ Goodwin Jr., J. W. (1986). Op. Cit., p. 105.

${ }^{30}$ Batista, C. S. (2012). A opinião pública e os escravos em um núcleo urbano da Zona da Mata mineira, Juiz de Fora 1870 - 1888. Disponível em: <http://web.cedeplar.ufmg.br/cedeplar/seminarios/ecn/ecnmineira/2012/arquivos/A\%20opini\%C3\%A30\%20p\%C3\%BAblica\%20e\%20os\%20escravos\%20em\%20um\% 20n\%C3\%BAcleo\%20urbano.pdf>. Acesso em: 23 abr. 2014.

${ }^{31}$ Ibidem, p. 10.
} 
nos anos finais do escravismo em Juiz de Fora se explica pelo fato de que, a partir de 1881, as autoridades locais passaram a prestar contas à população em relação às prisões de escravos feita pela polícia. Este mecanismo foi utilizado para demonstrar que a paz predominava na região e que a ordem pública estava sendo mantida.

Um dos grandes temores em relação à presença dos negros na cidade era quanto à sua socialização. Em Juiz de Fora havia locais onde os escravos podiam se socializar com os demais moradores, no entanto estes ajuntamentos causavam certo temor à sociedade, pois a junção de forros, cativos e brancos poderia desencadear em crimes ou desordens, com destaque para região do Largo do Riachuelo. Nos locais de sociabilidade eram comuns os batuques e zungus, os quais eram alvo de preocupação das autoridades. Nesse sentido, o Código de Posturas de Juiz de Fora de 1858 proibiu tais práticas $^{32}$.

A partir de 1876 os crimes cometidos por escravos, bem como os de outra natureza, passaram a ser julgados em Juiz de Fora, a qual foi elevada à Comarca. De acordo com Carneiro ${ }^{33}$, a maioria dos juízes e advogados que atuavam na Comarca pertencia à elite política e econômica local e, em muitos casos, até mesmo à elite política estadual e nacional. Segundo o historiador, o judiciário local era formado pela essa mesma elite preocupada em ordenar o espaço público através da regulamentação das Posturas Municipais e da vigilância das ruas, o que produzirá efeito, sobretudo, no âmbito criminal, haja vista que todo esse aparato funcionava como estratégia de regulação do contingente que ameaçava a ordem desejada pelas classes dominantes ${ }^{34}$.

Pelo fato desses advogados e juízes serem membros da elite local, no curso dos processos criminais 35 ,"esses membros da elite local, atuando na esfera da justiça e do

\footnotetext{
${ }^{32}$ Artigo 149 - É prohibida a dança de batuque nas casas da Povoações com algazarra, de dia ou de noite, de sorte que incomode as visinhanças: pena desfazimento do ajuntamento, e a multa de $2 \$$ [dois mil réis] por cada pessoa que fôr achada no batuque. Fonte: AHJF, Fundo Câmara do Império. Série 163: posturas da Câmara Municipal da Cidade do Paraibuna da Província de Minas Gerais apud Batista, C.S. (2012). Op. Cit., p.12.

${ }^{33}$ Carneiro, D. F. (2011). O Tribunal e seus casos: um perfil da Justiça e dos Processos Criminais de Calúnia e Injúria em Minas Gerais (JUIZ DE FORA - 1854/1941), Rio de Janeiro: TJRJ. Disponível em: <http://www.tjrs.jus.br/export/poder_judiciario/historia/memorial_do_poder_judiciario/memorial_judiciario_ga ucho/revista_justica_e_historia/issn_1677-065x/v9n17n18/O_TRIBUNAL.pdf>. Acesso em: 23 abr. 2014.

${ }^{34}$ Ibidem, p. 3.

${ }^{35}$ Durante o período imperial, dentre as infrações apuradas destacam-se homicídios (267) e tentativas de homicídios (144), ofensas físicas (417), ameaças (32), furtos (102), roubos (106), dano (71), calúnia, injúria e difamação (294), resistência e desobediência (30), além de ofensas às leis de posturas (20) ${ }^{35}$. Cumpre ressaltar que, nos crimes contra as pessoas e contra a propriedade, é maciça a presença de imigrantes e trabalhadores pobres. Matos, L. P. (2008). "Entre vozes e discursos: a análise da documentação criminal
} 
direito buscaram impor uma noção de ordem social que perpassava pelas relações comunitárias, condenando aqueles com atitudes públicas consideradas impróprias e ordenando relações sociais"36.

Ao pesquisar o padrão da criminalidade escrava em Juiz de Fora, Elione Guimarães $^{37}$ chegou à conclusão de que os crimes contra a pessoa, ou seja, aqueles que afetavam um indivíduo predominaram entre a população escrava juizforana ${ }^{38}$. Mesmo com um número reduzido de notícias sobre crimes de escravos urbanos juizforanos, foi possível perceber que o roubo, que é considerado um delito contra a pessoa, predominou entre a população escrava do núcleo urbano de Juiz de Fora. Ao cometerem algum crime, estes cativos estavam sujeitos a uma série de punições como reclusão, açoites, trabalhos forçados em obras públicas, andar com ferros ao pescoço, dentre outros.

Conforme destaca Almeida ${ }^{39}$, ancoradas nessas demandas por ordem do período, a persecução penal passou a ocupar posição de destaque no cenário local. Esses são os primeiros sintomas apresentados em Juiz de Fora daquilo que Nilo Batista, que viveu na cidade quando de sua juventude e é considerado hoje como um dos maiores penalistas brasileiros, chama de programação criminalizante no Brasil ${ }^{40}$. Por meio da política criminal levada a efeito na primeira República ${ }^{41}$, medidas de controle social direcionadas à vigilância e repressão dos comportamentos tidos como não conformes aos padrões de urbanização, higiene e ordem propugnados à época foram incorporadas às práticas policiais e leis penais. Sob o signo do perigosismo, aqueles que não conseguiam se colocar no mercado de trabalho e/ou não se adequavam às regras de comportamento estabelecidas pelas classes dominantes, eram considerados vadios, mendigos, desordeiros, vagabundos.

para o estudo da imigração em Juiz de Fora no final do século XIX". In Anais / II Colóquio do LAHES. Disponível em: <http://www.lahes.ufjf.br>. Acesso em: 23 abr. 2014.

${ }^{36}$ Carneiro, D. F. (2011). Op. Cit., p. 7.

${ }^{37}$ Guimarães, E. S. (2006). Violência entre parceiros de cativeiro: Juiz de Fora, segunda metade do século XIX, São Paulo: Annablume, p. 85.

${ }^{38}$ Ibidem.

${ }^{39}$ Almeida (2004, p. 61 apud Musse, C. F. (2006). Op. Cit., p. 61).

40 Batista, N. (2006), "História da programação criminalizante no Brasil". In Zaffaroni, E.R. et al. (2006). Direito Penal Brasileiro: primeiro volume - Teoria Geral do Direito Penal, Rio de Janeiro, Revan, p. 411 a 481.

${ }^{41}$ Ibidem; Batista, V.M. (2003). O medo na cidade do Rio de Janeiro. Dois tempos de uma história, Rio de Janeiro: Revan; Rauter, C. (2003). Criminologia e Subjetividade no Brasil, Rio de Janeiro: Revan. 
Ao justificar a intromissão e a intervenção do Estado tanto na vida pública quanto na vida privada dos indivíduos, as medidas adotadas revelavam seu caráter autoritário. Conforme destacado por Nilo Batista,

[...] a programação criminalizante da primeira República brasileira espelha as contradições de um sistema penal que participa decisivamente da implantação da ordem burguesa [...] a partir da própria concepção, cara ao positivismo e por sua iniciativa inscrita na bandeira republicana, de ordem ${ }^{42}$.

Assim como em outras cidades brasileiras à época, orientadas pelo ideário positivista, as políticas públicas desenvolvidas em Juiz de Fora, com vistas à sua adequada urbanização, funcionaram, como no dizer da criminóloga Vera Malaguti Batista, "como um grande catalisador da violência e da desigualdade característica do processo de incorporação da nossa margem do capitalismo central'43. As medidas de repressão e segregação eram justificadas a partir da ideia de que a tolerância levaria à desordem e à entrada do caos, o que poderia ameaçar o tão almejado desenvolvimento da nação. Nesse sentido, o projeto de construção da ordem burguesa no país foi erguido a partir do mito do sujeito perigoso, ameaçador do progresso e da paz social. É nessa época que se pontifica, segundo Vera ${ }^{44}$, o conceito de classes perigosas:

[...] perigosas porque pobres, por desafiarem as políticas de controle social no meio urbano e por serem consideradas propagadoras de doenças. [...] No Brasil, a difusão do medo do caos e da desordem tem sempre servido para detonar estratégias de neutralização e disciplinamento planejado do povo brasileiro ${ }^{45}$.

Trabalhos como o de Christo $^{46}$, revelam o papel fundamental que os processos de marginalização e segregação sofridos pelos imigrantes, negros e pobres nesse período exerceram na configuração territorial da cidade. Após as medidas sanitaristas de destruição dos cortiços e das hospedarias - que determinou a expulsão destes moradores do centro urbano ainda no final do século XIX - Juiz de Fora passou a vivenciar o início da ocupação desordenada da periferia.

\footnotetext{
${ }^{42}$ Batista, N. (2006), Op. Cit. p. 456-457.

${ }^{43}$ Batista, V.M. (2011). Introdução crítica à criminologia, Rio de Janeiro: Revan. p. 48.

${ }^{44}$ Batista, V.M. (2003). Op. Cit., p.37.

${ }^{45}$ Ibidem, p. 52-53.

${ }^{46}$ Christo, M. C. V. (1994). Europa dos pobres: Juiz de Fora na Belle Époque Mineira, Juiz de Fora, MG: EDUFJF.
} 
Na década de 1910 e 1920 algumas resoluções foram emitidas pela Câmara Municipal no sentido de evitar o acúmulo de operários, pobres e vadios no centro da

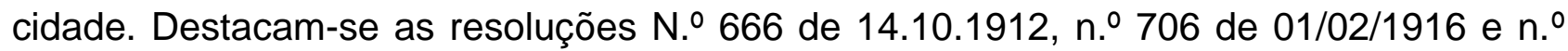
869 de 02.05.1921, que tratam respectivamente da isenção de imposto para a construção de casas de operários, da proibição da construção de avenidas para moradias no centro e da proibição de indivíduos sem profissão também na área central, medida determinantes para o processo de periferização que se agravou no decorrer dos anos devido à falta de estrutura dada a estas regiões ${ }^{47}$.

A despeito dessas consequências advindas para as classes menos favorecidas, os impulsos para o crescimento da cidade na segunda metade do século XIX trouxeram os resultados pretendidos pelos agentes de poder. Na década de 1920, Juiz de Fora era 0 maior centro industrial de Minas, com uma forte concentração da indústria têxtil, como registra Maria Carlota de Souza Paula ${ }^{48}$. Nas décadas seguintes, porém, tal crescimento industrial não se manteve.

Conforme destaca Tasca ${ }^{49}$, na década de 30, o padrão industrial começou a decair, sofrendo os reflexos do declínio da economia cafeeira na Zona da Mata. A partir daí uma série de limitações e fragilidades relacionadas às diretrizes de política econômica adotadas para o País e à falta de visão estratégica dos agentes econômicos locais para a modernização e diversificação do parque fabril, levou o Município a um processo de modificação na sua estrutura econômica. Tais mudanças lhe imprimiram à cidade um novo perfil: "perdendo o antigo ímpeto de crescimento industrial, modificaram-se as relações com os demais municípios da região e a cidade se transformou, de centro comercial atacadista, em polo regional prestador de serviços".

A partir de 1950, a economia urbana da cidade manteve-se através atividades terciárias que se tornaram tradicionais, como os serviços de educação e saúde, que se ampliaram atendendo não somente à população da Zona da Mata, mas também, outras cidades mineiras e do Estado do Rio de Janeiro. A rede de estabelecimentos comerciais, especialmente varejista, também merece destaque tendo importância regional na distribuição de bens e mercadorias, contribuindo para o incremento da economia. Aos poucos a cidade foi se rendendo à sua nova vocação, que será confirmada na década

\footnotetext{
${ }^{47}$ Almeida, R. (2005). Op. Cit., p. 4.

${ }^{48}$ Paula (1976, p. 66 apud Musse, C. F. (2006). Op. Cit.)

${ }^{49}$ Tasca, L. (2010). Op. Cit., p. 106.
} 
seguinte: de cidade industrial, transforma-se em centro prestador de serviços. Tal vocação foi corroborada na década de 1960, com a criação da Universidade Federal de Juiz de Fora ${ }^{50}$.

Ao final da década de 1960, no entanto, novos impulsos de crescimento foram observados, a população urbana passou, de acordo com o IBGE, de 181.389 habitantes em 1960, para mais de 238 mil em 1970. Mas, conforme o ocorrido na primeira fase desenvolvimentista, esse reaquecimento econômico e populacional também foi o motor de uma série de mudanças no âmbito das políticas de urbanização e controle social da população juiz-forana. Segundo Christiane Silva de $A b r e u^{51}$, ao final dos anos sessenta passa-se a observar um aumento expressivo no deslocamento das populações em direção a bairros mais afastados.

\section{A segunda velocidade da modernização}

Segundo Christiane $A b r e u^{52}$, não é possível definir com precisão o período do surgimento das favelas na cidade. Contudo, na década de 1960 elas começaram a marcar mais expressivamente o espaço urbano. Reportagens da série intitulada "O drama das favelas", do jornal Diário da Tarde, do ano de 1961, descreviam a situação de miserabilidade de diversas famílias que ocupavam favelas na zona leste de Juiz de Fora.

Ao longo da década de 1960, a classe média juiz-forana mostrou-se aterrorizada com a expansão das favelas na cidade e com os perigos que poderiam advir desse processo. Como destaca $\mathrm{Abreu}^{53}$, a imprensa - que de certa forma refletia a opinião da sociedade - declarava que antes do surgimento das favelas:

Juiz de Fora, foi uma cidade feliz. [...] Existe agora, [1967] entre nós a ameaça de um problema que atormenta a vida de uma cidade grande. Até agora, o único lugar que se assemelhava um pouco a uma favela é o lugar conhecido como - Buraco do Olavo. Mas, agora, a situação é diferente ${ }^{54}$.

\footnotetext{
50 Ibidem, p. 109.

${ }^{51}$ Abreu, C. S. (2010). "Favelas em Juiz de Fora: a ocultação do fenômeno". In Libertas, Juiz de Fora, v.4, n. 1 , p. $146-170$.

52 Ibidem, p. 3.

53 lbidem, p. 12.

${ }^{54}$ Diário Mercantil, Juiz de Fora, 09 e 10 jul. 1967. p.6. apud Abreu, C. S. (2010). Op. Cit., p. 12
} 
De modo a atender aos anseios das classes dominantes, numa tentativa de impedir a expansão das favelas nas regiões próximas ao centro, o então Prefeito Itamar Franco, determinou que todas as tentativas de ocupação nessas regiões fossem violenta e incisivamente abafadas, conforme reportagem veiculada no Diário Mercantil em 1967:

Todo barraco que fôr (sic) iniciado, será derrubado imediatamente [...] essa medida vem sendo cumprida sem o menor problema [...] Em seguida à proibição, foi feita uma notificação aos favelados, para que eles (sic) procurem, o mais depressa possível, um outro local para morar ${ }^{55}$.

Os problemas decorrentes do processo de segregação no espaço urbano da cidade, marcado por arbitrariedades e desrespeito aos direitos humanos das classes pauperizadas, tiveram ampla cobertura na imprensa local. Em agosto de 1977 o jornal Diário Mercantil, ao relatar o drama dos moradores de uma favela no bairro Ladeira, na zona leste da cidade, denunciava que, depois de expulsos de seu lugar de moradia, os moradores foram alojados em estábulos do Jóquei Clube, na zona norte da cidade, bem distante do centro urbano, com a promessa de que seria transferidos para lotes urbanizados o mais rápido possível, o que não ocorreu - tendo os moradores permanecido por mais de um ano nos estábulos, até serem "jogados na Vila Olavo Costa, zona sul da cidade, mais conhecida na época como "buraco do Olavo"

Situação semelhante ocorreu com a antiga favela Vila da Prata, situada, na década de 1970, entre os bairros Teixeiras e Aeroporto. Os moradores foram retirados do local após fortes pressões para a construção de um parque municipal, o atual Parque da Lajinha. Destaca-se que, no ano de 1979 novas remoções foram empreendidas no local para a construção do acesso que ligaria as cidades de Juiz de Fora e Rio de Janeiro, um trecho da rodovia BR-040, situada então no entorno do parque que seria construído, o que determinou a retirada de mais moradores do local e sua transferência para o bairro Santa Efigênia. O restante dos moradores resistiu às pressões e ainda permaneceu no local até o ano de 1981, até que medidas mais intensas foram tomadas e resultaram na expulsão dramática e cruel de todos os moradores da Vila da Prata.

\footnotetext{
${ }^{55}$ Diário Mercantil, Juiz de Fora, 29 jul. 1967. p.6 apud ibidem, p. 12.

${ }^{56}$ Abreu, C. S. (2010). Op. Cit., p. 4.
} 
No local havia cerca de cem famílias que foram removidas para o bairro Santo Antônio em loteamentos sem a mínima infraestrutura, para que finalmente a Vila da Prata fosse totalmente destruída para dar lugar ao Parque da Lajinha ${ }^{57}$. Os primeiros moradores da região do Alto Santo Antônio foram removidos da Vila da Prata por cerca de 100 funcionários da Prefeitura, 20 policiais, políticos e representantes de entidades, procederam às desocupações violentas do local, expulsando as famílias, destruindo as casas e carregando a mudança das famílias desalojadas para o ponto mais alto do bairro para casas sem banheiros, janelas, portas, piso ou forro. Não havia água, luz, esgoto, iluminação e apenas uma mina a 500m de distância, indo contra, inclusive, ao código de posturas municipais. Tudo isto, por um ato político, que visava tornar mais agradável uma das entradas da cidade ${ }^{58}$.

Esse conjunto de reformas urbanas que culminou no aumento da periferia em Juiz de Fora - e na consequente expulsão dos pobres urbanos dos seus lugares de moradia ocorreu com mais frequência na administração do Prefeito Francisco Antônio de Mello Reis $^{59}$, entre os anos de 1977 e 1982. Ressalta-se que as reformas urbanas empreendidas por Mello Reis, embora fossem justificadas sob a promessa de redução das desigualdades e aumento da qualidade de vida de toda a população, terminaram por beneficiar os setores econômico e industrial e a classe média, em detrimento das classes menos favorecidas. Senão, vejamos. O conjunto de intervenções urbanísticas realizadas pelo ex-prefeito estava inserido no Projeto Cidades de Porte Médio (CPM II). Ao final dos anos 70, Juiz de Fora foi incluída no projeto CPM - Centro de Porte Médio financiado pelo Banco Interamericano - BIRD.

O projeto destinava-se a centros urbanos classificados como de porte médio devido à sua posição geográfica, população, importância sócio-econômica, função regional significativa, e pretendia incrementar seu desenvolvimento com vistas a estruturação de uma rede urbana equilibrada. As diretrizes do Banco Mundial para o financiamento de

\footnotetext{
${ }^{57}$ Ibidem, p. 4-6.

${ }^{58}$ Almeida, R. (2005). Op. Cit., p. 8.

${ }^{59}$ Francisco Antônio de Mello Reis foi filiado à ARENA, PDS, PFL e DEM. Eleito prefeito de Juiz de Fora em novembro de 1976 (sendo o único Arenista eleito para tal função em Juiz de Fora), para mandato de 1977 a 1981, depois prorrogado até 1983. Em sua administração foram realizadas diversas obras que destinadas ao desenvolvimento da cidade tais como: instalação da Siderúrgica Mendes Júnior, transposição da linha férrea pela Avenida Rio Branco (Mergulhão), reordenação do transporte público, incorporação da Companhia Mineira de Eletricidade pela CEMIG, construção do acesso da cidade à nova BR-040, início das obras do novo terminal rodoviário e estádio municipal. www.pjf.mg.gov.br, acessado em 23 abr. 2014.
} 
projetos de melhorias urbanas em países do Terceiro Mundo propunham especificamente gerar impacto sobre a pobreza urbana.

Projetos dessa natureza foram amplamente estimulados na conjuntura econômica da ditadura militar no início da década de 1970, período conhecido como o do "milagre econômico brasileiro" (1968/1973). As medidas assinalavam a preocupação com o planejamento de desenvolvimento econômico em geral, inclusive através de planos formais, a partir daí institucionalizados o Plano Nacional de Desenvolvimento - PND. Mas a hegemonia do Conselho Monetário Nacional no comando e a coordenação econômica deu mais força à estratégia macroeconômica do que a qualquer projeto de desenvolvimento industrial/tecnológico. Prevalecia, nesse momento, 0 chamado desenvolvimentismo nacionalista e o intervencionismo estatal, "que amalgamavam as forças políticas e os interesses econômicos do projeto industrializante. Nesse sentido, o governo ocupava-se prioritariamente com os interesses econômicos e crescimento da indústria, procurando fazer com que a estrutura industrial convergisse para o padrão estrutural das economias industrializadas" ${ }^{\prime 60}$.

O município de Juiz de Fora, cuja administração fomentava a consecução de tais objetivos, recebeu verbas e assessoria técnica para operar sobre 3 metas: investimento em infraestrutura e serviços urbanos; geração de emprego e renda e melhoria da administração pública. Neste contexto, a gestão do prefeito Mello Reis voltou-se à modernização da malha viária da cidade, produzindo impactos no sentido do arco suloeste-norte da cidade, através da inserção de novos territórios para expansão do mercado imobiliário, do distrito industrial e criação de conjuntos ou loteamentos de moradias populares, os quais não receberam a devida assistência por parte da administração local.

Ao final das obras, foi possível perceber que o PCM, sob a administração do referido prefeito, trouxe intervenções pontuais sobre a área central da cidade, a construção do Distrito Industrial (o que atraiu a vinda de indústrias) e os acessos a cidade Alta - região do São Pedro (que beneficiaram a comunicação com campus universitário e a valorização de bairros para moradias de classe média, além dos acessos a rodovia BR

\footnotetext{
${ }^{60}$ Souza, M. (2012). "É Hora de Mudar: A política industrial de Getulio Vargas e Lula". In Anais da XXIX Semana de História da Universidade Federal de Juiz de Fora, Juiz de Fora: UFJF, p. 549. Disponível em: <http://www.ufjf.br/semanadehistoria/files/2010/02/Anais-da-Semana-de-Hist\%C3\%B3ria-20122.pdf>.

Acesso em: 24 abr. 2014.
} 
040, principalmente no eixo sudoeste ao longo da avenida Independência, atualmente um dos espaços mais valorizados da cidade ${ }^{61}$. Esse conjunto de reformas permitiu que na década de 1980 a cidade começasse a trilhar uma nova fase no seu desenvolvimento industrial. Foi no início dessa década que a cidade passou a sediar duas importantes indústrias de base: a Siderúrgica Mendes Júnior e a Companhia Paraibuna de Metais. A partir de junho de 1980, a Companhia Paraibuna de Metais, atual Votorantim, inaugurava sua unidade em Juiz de Fora. No segundo semestre do mesmo ano, a Siderúrgica Mendes Júnior, posteriormente denominada Belgo e atual ArcelorMital, iniciava suas atividades na cidade e, em 1984, entrava em operação comercial. Mais tarde, em 1996, a Mercedes-Benz instalava uma montadora em Juiz de Fora ${ }^{62}$.

No entanto, para promover a esperada renovação urbana e o reaquecimento do setor industrial o prefeito Mello Reis realizou, segundo Abreu ${ }^{63}$, uma "verdadeira operação de guerra contra os pobres", expulsando-os de toda área que fosse passível de valorização. Tais remoções, porém, não vieram acompanhadas de políticas públicas eficientes e devidamente planejadas para garantir condições dignas de sobrevivência a esses cidadãos, tampouco garantir o acesso a direitos básicos como saneamento, transporte, educação, saúde, lazer, cultura e segurança pública - situação que persiste na maioria desses locais na atualidade.

Além de todos os problemas atinentes ao acesso aos direitos básicos, o principal drama que vai circunscrever esses núcleos pauperizados que se avolumaram nas regiões de periferia de Juiz de Fora se relaciona à percepção social por parte do restante da cidade em relação aos indivíduos moradores desses locais, os quais passaram a ser associados à marginalidade. À sombra dos discursos perigosistas que rondaram 0 município nas primeiras décadas no século $X X$, atualiza-se a imagem dos moradores de periferia a partir de um estado permanente de suspeição, com um estigma de inferioridade perante os outros moradores da cidade. No período, os indicadores de criminalidade no município eram baixos se comparados aos grandes centros urbanos do país, no entanto - a despeito dos reduzidos índices de violência - as medidas de

\footnotetext{
${ }^{61}$ Disponível em: <http://www.ufjf.br/latur/files/2010/12/Hist\%C3\%B3rico-Mello-Reis.pdf>, acessado em 23 abr. 2014.

${ }^{62}$ Almeida, F. A. (2011). "Os Movimentos Populares em Juiz de Fora nos Anos 80". In Anais da XXVIII Semana de História da Universidade Federal de Juiz de Fora, Juiz de Fora: UFJF, p. 316. Disponível: <http://www.ufj.br/semanadehistoria/files/2011/08/Anais-da-XXVIII-Semana-de-Hist\%C3\%B3ria-2011.pdf>. Acesso em: 24 abr. 2014.

${ }^{63}$ Abreu, C. S. (2010). Op. Cit., p. 4.
} 
vigilância e repressão estavam presentes, direcionadas quase que prioritariamente às periferias e às ruas do centro ${ }^{64}$.

Conforme destaca $\mathrm{Abreu}^{65}$, uma das ações de maior destaque nesse período foi a denominada "Operação-Gente", uma operação com pretensões de tornar a cidade mais humana. "Remover para humanizar", esse foi o procedimento padrão que definiu os rumos do planejamento urbano em Juiz de Fora durante a administração Mello Reis e gerou grande descontentamento entre os núcleos populares e representantes dos setores de defesa dos direitos humanos.

No início dos anos 1980, depois de muitas remoções, a situação dos pobres nas regiões centrais da cidade foi controlada e a prática de remoções deixou de prevalecer em Juiz de Fora. Em 27 de agosto de 1987, o então prefeito Tarcísio Delgado, sancionou a lei Lei $\mathrm{n}^{\circ}$ 7152, que dispõe sobre a incorporação e a constituição da Empresa Regional de Habitação de Juiz de Fora S.A - EMCASA. Conforme reportagem veiculada no jornal Tribuna de Minas em 1997, mesmo com a criação da EMCASA, os problemas quanto à moradia e adequação do espaço urbano continuavam sendo um dos maiores desafios a serem solucionados pela administração municipal ${ }^{66}$. A partir de tentativas tímidas de regularização da propriedade da terra e da moradia, e de loteamentos de áreas para a construção de casas populares, a administração local passou a conviver com a demanda de mais de 15 mil famílias, situação que foi se tornando ainda mais complexa ao longo da última década ${ }^{67}$.

\section{Os novos tempos e os impactos do crescimento}

Os impulsos para o crescimento da década de 1970 percebidos em Juiz de Fora, e no país como um todo, não se perpetuaram ao longo dos anos 1980, sobretudo a partir da crise macroeconômica que se instalou a partir de 1980-81 e das transformações políticas e sociais decorrentes do processo de redemocratização do país após mais de duas

\footnotetext{
64 Ibidem.

${ }^{65}$ Ibidem, p. 10.

${ }^{66}$ lbidem, p. 8-9.

${ }^{67}$ Ver: Distribuição numérica de tipos de loteamentos, casas e apartamentos realizados pela EMCASA em Juiz de Fora, 1997-2010 (1). Disponível em: <http://www.cps.ufjf.br/anuarios/Anuario2012/index.html>, acessado em 21 abr. 2014.
} 
décadas de ditadura militar ${ }^{68}$. Na década de 1990, influenciado por políticas neoliberais, 0 Brasil assistiu uma maior abertura aos investimentos estrangeiros e a retirada do Estado como agente do desenvolvimento industrial. Com o abandonado do sistema de fomento à indústria e o início de um amplo processo de privatizações de indústrias e de infraestrutura, uma série de mudanças econômicas submeteu o setor industrial, enfraquecido por anos de estagnação, à concorrência predatória de importações e investimentos estrangeiros, resultando em fortes processos de desnacionalização, pressões setoriais por proteção, crises devido às políticas estaduais de atração de investimentos, desemprego crescente e enfraquecimento das relações trabalhistas, reflexos que também puderam ser sentidos no município de Juiz de Fora ${ }^{69}$.

A partir de 2003 sob o governo de Luiz Inácio Lula da Silva, políticas direcionadas a setores portadores de dinamismo e setores chaves para a economia nacional começam a ser retomadas ${ }^{70}$. O governo Lula defendia o objetivo de crescimento, gerando emprego e distribuindo renda, com destaque para a retomada do desenvolvimento industrial brasileiro. Dentro da proposta de crescimento e desenvolvimento industrial do Brasil e o estimulo a inovação tecnológica, o Brasil aumentou sua participação no comércio exterior. Em 2002 as exportações brasileiras eram de 0,96\% das exportações mundiais, já esse número em 2005 chegou a 1,17\% ${ }^{71}$.

Em Juiz de Fora, as políticas governamentais tiveram destacada atuação, contribuindo para a vinda de empresas e crescimento dos indicadores econômicos. A preocupação com a retomada desenvolvimento é traço marcante do período, o que pode ser percebido através da análise do Plano Diretor de Desenvolvimento Urbano (PDDU, 2000) e do Plano Estratégico (PlanoJF de 1997). No entanto, como descreve Luciane Tasca, as políticas sociais não merecem destaque em tais projetos, os quais podem ser lidos como indicativos da permanência dos quadros de desigualdade social e conflitos urbanos no município. Senão, vejamos. A ideologia contida nos referidos modelos de planejamento estratégico e gestão da cidade, manifesta-se através de uma leitura

\footnotetext{
${ }^{68}$ Souza, M. (2012). Op. Cit.

${ }^{69}$ lbidem, p. 549.

${ }^{70}$ É lançada a Política Industrial Tecnológica e de Comercio Exterior - PITCE, que foi concebia para atingir seus resultados em longo prazo e sua principal preocupação é com a inovação e a agregação de valor aos processos produtivo, e posteriormente o Plano de Desenvolvimento Produtivo - PDP. A Política Industrial Tecnológica e de Comercio Exterior - PITCE, que foi concebia para atingir seus resultados em longo prazo e sua principal preocupação é com a inovação e a agregação de valor aos processos produtivo. Souza, M. (2012). Op. Cit., p. 550.

${ }^{71}$ Ibidem, p. 557.
} 
homogeneizadora da sociedade, produzindo a diluição das diferenças sociais, unificando todos os habitantes em torno de determinadas ações que contemplam interesses parciais. Dessa forma, o ponto de vista dos grupos dominantes aparecem como o mais adequado para toda a população, priorizando seus interesses como se correspondessem ao interesse de todos os membros da sociedade. Na prática, pode-se entender tais planos como uma articulação de ações públicas e privadas, voltada principalmente para a revitalização econômica da cidade, galvanizada por discursos como a conservação do meio ambiente, um maior equilíbrio social e desenvolvimento sustentável. Assume destaque, portanto, a atração de investimentos para a cidade, que a dotem de maior infraestrutura urbana, sobretudo nos setores de transportes e telecomunicações, capazes de reforçar sua posição de centro de serviços para toda a região ${ }^{72}$.

Percebe-se portanto, que a despeito das estratégias político-econômicas adotadas no âmbito municipal, em sintonia com a política do governo federal, os problemas decorrentes dos impactos do crescimento desordenado, sobretudo aqueles havidos na década de 1970, ainda estão presentes no cotidiano da cidade. Nesse sentido, Juiz de Fora não estaria isolada das demais cidades médias brasileiras que passaram por fluxos desordenados de crescimento e adotaram medidas incipientes para a reorganização do espaço urbano. No ano de 2009, sob a promessa de contemplar essa demanda nacional e estabelecer uma política eficiente de moradia e melhoria das condições de vida nos núcleos urbanos, o governo federal estabeleceu novos rumos para a política nacional de habitação, os quais também irão incidir na conjuntura social juiz-forana.

A partir do ano de 2008, em razão da crise econômica internacional que, ao adquirir contornos preocupantes, afeta a economia brasileira, observa-se o início de retração econômica e desaceleração do PIB nacional. A partir de então, o Governo Federal, além de expedir medidas de incentivo à liquidez na economia doméstica (mudança nas regras do recolhimento sobre depósitos compulsórios) e das políticas de estabilização cambial (leilões de parte das reservas cambiais, com o objetivo de estabilizar a cotação do dólar), passa a criar estímulos diretos à atividade econômica. Parte desses estímulos se concentrou no setor da construção civil e infraestrutura, setor que apresenta relevante papel tanto na geração de emprego quanto no comportamento do PIB. Dentre as principais medidas para investimentos na construção civil destaca-se o

\footnotetext{
${ }^{72}$ Tasca, L. (2010). Op. Cit., p.97-98.
} 
programa habitacional Minha Casa, Minha Vida (PMCMV), destinado à população de baixa renda. Com investimentos da ordem de $R \$ 34$ bilhões (sendo $R \$ 25,5$ bilhões do Orçamento Geral da União, $R \$ 7,5$ bilhões do FGTS e $R \$ 1$ bilhão do BNDES), o Programa prevê a construção de um milhão de moradias no prazo de dois anos, além da promessa de geração de emprego e renda ${ }^{73}$.

Nos últimos dois anos, a chegada do PMCMV em Juiz de Fora, como veremos, ao invés de trazer os benefícios prometidos à cidade, terminou por reascender os debates acerca dos problemas de urbanização, violência e políticas públicas, cujos maiores impactos recaíram no âmbito da segurança pública. Nesse período, a crença do juizforano em relação ao aumento da criminalidade no município ${ }^{74}$ e sua relação com os moradores dos bairros da periferia, sobretudo aqueles situados à zona norte e nas regiões dos conjuntos habitacionais do programa Minha Casa, Minha Vida (PMCMV), tem sido crescente.

Nesse sentido, os apelos pela redução da criminalidade através de medidas de vigilância e repressão nas ruas do centro da cidade e nas áreas de periferia, sobretudo aquelas onde estão localizados os condomínios do PMCMV, têm sido crescentes. Em Juiz de Fora, as percepções acerca da violência giram em torno de um consenso sobre o tema, o qual relaciona-a sempre às zonas de favela, ou regiões ocupadas por moradores de rua, usuários de drogas, mendigos, ambulantes, crianças e adolescentes em situação de rua e regiões marcadas pelo tráfico de drogas. Tal associação, na maioria das vezes, concebe a violência como decorrente de culpa individual dos sujeitos ativos e ensejadora de intervenções urbanas enérgicas. As regiões de periferia são, assim, identificadas como

\footnotetext{
${ }^{73}$ Romagnoli, A. (s.d.) O programa "minha casa, minha vida": continuidades, inovações e retrocessos. São Paulo:UNESP. Disponível em: <http://www.fclar.unesp.br/Home/Departamentos/AdministracaoPublica/RevistaTemasdeAdministracaoPubli ca/artigoalexandreromagnoli.pdf>, acessado em 25 abr. 2014.

74 De acordo com o diagnóstico da criminalidade violenta em Juiz de Fora desenvolvido no ano de 2008 por pesquisadores da UFJF, à pedido da Secretaria de Estado de Defesa Social (SEDS), do qual pude participar, é possível verificar que a dita "escalada da violência", que vem despertando insegurança social e pânico moral na cidade não está adstrita aos últimos dois anos. Conforme os dados da pesquisa, nos anos de 2005 e 2006 o crime violento esteve bastante presente na cidade, com destaque par a presença de armas de fogo, estando tais crimes violentos concentrados em bairros que possuem zona comercial e bancária estruturadas, população de classe média e classe média alta, com renda média de três ou mais salários mínimos. É justamente esse mesmo segmento da população que vem pugnando, desde então, pelo recrudescimento dos programas de segurança pública na cidade. A novidade dos últimos dois anos é que o número de crimes violentos cresceu ainda mais, sendo que a maior incidência destes atualmente tem sido nas áreas de periferia próximas aos condomínios do PMCMV, o que tem servido para reforçar os apelos pelo recrudescimento no âmbito da segurança pública, bem como seu devido direcionamento às áreas de periferia. Disponível em: <http://www.ufjf.br/secom/2008/10/16/pesquisadores-da-ufjf-divulgam-diagnosticoda-criminalidade-violenta-em-juiz-de-fora/>, acessado em 25 abr. 2014.
} 
locus do mal, onde situam-se os membros "mais visíveis das multidões perigosas". Como assinala Vera Malaguti, um dos traços mais marcantes do nosso tempo é justamente a identificação da sociedade com um controle social e punitivo dos contingentes humanos que ela mesma marginaliza ${ }^{75}$.

Ao invés de estabelecer maiores reflexões acerca dessas ponderações destacadas por Vera Malaguti ${ }^{76}$, em Juiz de Fora, assim como em outras cidades brasileiras, que passaram a enfrentar o problema do crescimento da violência nos últimos anos, as políticas de enfrentamento estabelecidas no município, como se verá à frente, vêm apostando na repressão e no aumento dos níveis de encarceramento. Tais medidas distanciam-se de programas de prevenção baseados em políticas afirmativas e melhorias das condições de vida e bem-estar nas regiões mais violentas, o que contribuindo sistematicamente para o seu fracasso ao longo do século $\mathrm{XX}$.

\section{A nova Juiz de Fora e suas antigas contradições ${ }^{77}$}

No dia 22/05/2013 o MGTV ${ }^{78}$ - telejornal local - discutiu a situação do aumento da violência nos condomínios populares em Juiz de Fora (recém-lançados pelo programa "Minha Casa, Minha Vida"), com destaque para o crescimento do número de homicídios. A reportagem abordou ainda, embora com menos destaque, que além das questões de segurança, os moradores dos conjuntos habitacionais "Minha casa, Minha vida" em Juiz de Fora, como Parque das Águas, Belo Vale e Nova Germânia, vêm enfrentando outros problemas nas unidades. Segundo o noticiário, cerca de 2.600 famílias moram nestes condomínios, as quais têm visto o "sonho da casa própria" transformar-se em uma dura

\footnotetext{
${ }_{75}^{75}$ Batista, V.M. (2003). Op. Cit. p.106-107,113.

76 Ibidem.

77 “A NOVA JUIZ DE FORA E A REESTRUTURAÇÃO DO CENTRO URBANO" - era o lema de campanha do então candidato do PMDB à prefeitura, Bruno Siqueira, às eleições de 2013-2016, das quais saiu vitorioso. O projeto urbanístico de intervenção no centro da cidade, denominado "NOVA JUIZ DE FORA", além de outras abordagens, visa à reformulação de avenidas do centro da cidade, no sentido de conferir maior fluidez ao sistema viário, incentivando o uso do transporte coletivo, melhorias no trânsito e maior segurança e mobilidade para os pedestres. A "NOVA JUIZ DE FORA" tem como principais intervenções as avenidas: Rio Branco; Andradas; Getúlio Vargas e Independência, as principais vias da cidade, o que já constava do Plano Diretor de Desenvolvimento Urbano - 2004, onde este levanta sobre a necessidade de um plano de reestruturação viária, principalmente na área central.

${ }^{78}$ Disponível em: <http://megaminas.globo.com/2013/05/22/condominios-populares-de-juiz-de-fora-tem-altoindice-de-violencia>, acessado em 21 abr. 2014.
} 
realidade. Entre telhados soltos, eletrodomésticos perdidos durante as chuvas e o risco de desabamentos das encostas, o clima de insegurança generaliza-se.

A "escalada da violência"79 debatida em diversas reportagens dessa natureza vem sendo objeto de análise de diferentes segmentos desde 2012, bem como motivo de acentuada insegurança social entre os juiz-foranos. Segundo os dados da SEDS (Secretaria de Estado e Defesa Social), em 2012 e 2013 o número de homicídios e ocorrências policiais em Juiz de Fora aumentou em relação aos últimos dez anos ${ }^{80}$. Segundo os dados das Polícias Civil e Militar, tais ocorrências estão mais concentrados nas áreas dos referidos condomínios.

Diante disso, em março de 2013, diferentes setores da sociedade foram conclamados a se manifestar, com destaque para a $\mathrm{OAB}$, que procurou dar sua contribuição através da realização de um seminário na subseção de Juiz de Fora. $O$ evento reuniu autoridades, representantes da comunidade acadêmica e de movimentos sociais locais. Organizado em parceria com a Câmara Municipal, o seminário foi denominado "Violência Urbana em Juiz de Fora: O que deve ser feito?" e, segundo os organizadores, visava buscar respostas para resolver a crescente violência na cidade. Além do seminário, foram realizados laboratórios sobre a violência, os quais tinham por objetivo discutir, analisar e coletar dados, além de contemplar assuntos relacionados à Violência contra a Mulher; Violência e Saúde; População de Rua; Drogas; Violência contra o Idoso; Violência e Direito Penal; Violência e Arte; Violência no Trânsito; e outras vertentes da violência urbana.

No mês de maio de 2013 o poder público, através de lideranças policiais, representantes da Justiça, Ministério Público, Defensoria e Prefeitura definiu novos investimentos e obras para a criação da $4^{a}$ a Risp (Região Integrada de Segurança Pública), de modo a atender às expectativas sociais em relação à segurança pública na cidade.

Todas essas ações pretendiam oferecer uma resposta à sociedade em relação ao clima de insegurança que se inscreve na cidade, o qual tem sido alvo de críticas severas, sobretudo entre os núcleos de classe média. O crescimento da violência tem sido a tônica

\footnotetext{
${ }^{79}$ Disponível em: <http://www.tribunademinas.com.br/cidade/19-homicidios-revelam-escalada-da-violencia1.1074194>, acessado em 25 abr. 2014.

${ }^{80}$ Disponível em: <http://www.cps.ufjf.br/anuarios/Anuario2012/index.html>, acessado em 25 abr. 2014.
} 
das conversas informais nos cafés da região central da cidade, nos ônibus, nas faculdades, nas empresas e nos ambientes comerciais, o que pode ser entendido como um reflexo da ampla cobertura que os veículos de comunicação local vêm dando às ocorrências - nada ficando a dever à mídia sensacionalista dos grandes centros urbanos.

O fato da insegurança social e medo do crime passarem a tomar uma posição destacada no cotidiano da cidade nos últimos anos longe de ser um fenômeno isolado, relaciona-se a questões globais, como destacam Coimbra e Scheinvar ${ }^{81}$. Segundo as autoras, na contemporaneidade, o discurso da segurança passou a ser central na maioria das discussões. Os criminosos são vistos não como pessoas, mas meramente como sujeitos perigosos, estando presentes no eixo das falas,

seja em campanhas eleitorais, em análises institucionais, científicas ou em espaços privados. [...] Ao se falar das angústias sociais não estão presentes temas como: exploração do trabalho, desigualdade social, sentido mercantil das relações, lógica do capital que atravessa as políticas no Brasil e no mundo, privatização das riquezas, práticas totalitárias, pensamento fundamentalista [...]. Todos esses discursos não são referidos no clamor por segurança, endereçados ao controle das pessoas por meio do policiamento, do ajuizamento e da punição dos responsáveis pelas angústias que afligem nossa sociedade. [...] A vida íntima torna-se um produto ansiado como uma promessa de controle dos que causam o que é denominado como violência. Violência e intimidade constituem-se em um binômio imantado que rouba a cena [.....$^{82}$

Nesse sentido, de acordo com o jornal, Tribuna de Minas ${ }^{83}$, a "escalada da violência" em Juiz de Fora acentua a necessidade de implantação de um programa de segurança pública robusto e eficiente, tal como o principal projeto de segurança do Estado de Minas, denominado Fica vivo. Contudo, contrariando os apelos dos principais atores envolvidos, segundo os dados da $4^{a}$ Região da Polícia Militar, Juiz de Fora não possui as estatísticas que assinalariam sua inclusão no referido programa, pois - se comparado à taxa de homicídios por cem mil habitantes em municípios mineiros com população acima de 150 mil habitantes - o município ocuparia a $13^{\text {a }}$ posição ${ }^{84}$.

\footnotetext{
${ }^{81}$ Batista, V.M. (Org.) (2012). Op. Cit., p. 63.

${ }^{82}$ Coimbra, C.; Scheinvar, E. (2012). "Subjetividades punitivo-penais". In Batista, V. M. (Org.) (2012). Op. Cit., p. 60-68.

${ }^{83}$ Disponível em: <www.tribunademinas.com.br/cidade/19-homicidios-revelam-escalada-da-violencia1.1074194+\&cd=9\&hl=pt\&ct=clnk\&gl=br $>$, acessado em 25 abr. 2014.

${ }^{84}$ O Programa Fica Vivo tem por objetivo controlar e prevenir a ocorrência de homicídios dolosos em áreas com altos índices de criminalidade violenta em Minas Gerais, melhorando a qualidade de vida da população. Criado em 2003, é executado pela Coordenadoria Especial de Prevenção à Criminalidade
} 
Corroborando os dados informados pela Polícia Militar, o Anuário de 2012 desenvolvido pelo Centro de Pesquisas Sociais da UFJF divulgou que os índices de criminalidade e de vulnerabilidade juvenil de Juiz de Fora são baixos ${ }^{85}$, se comparados aos das maiores cidades mineiras.

No entanto, a despeito das estatísticas e dos contextos sociais que ensejam as situações de violência na cidade, os apelos pelo incremento nas políticas de segurança municipais terminaram por ensejar uma resposta nada original do poder público, a qual foi tão bem retratada por Michel Foucault em sua obra Vigiar e Punir. aumento da vigilância e do encarceramento.

Diante das negativas para a implantação do Fica Vivo, no mês de abril de 2013 - antes mesmo da realização de debates mais aprofundados sobre o tema da violência na cidade - o poder executivo, em parceria com a Polícia Militar, noticiou o projeto Olho vivo, que consiste na instalação de 21 equipamentos de vigilância e monitoramento em 54 pontos da cidade, as quais auxiliarão na captura e prisão dos autores. Ou seja, não se trata apenas de prender mais, mas de prender melhor - de forma rápida e eficiente. No projeto, vinte e um pontos da região central de Juiz de Fora deverão ser contemplados, cobrindo o quadrilátero formado pelas avenidas Rio Branco, Getúlio Vargas, Itamar Franco e Rua Benjamin Constant. Posteriormente, 16 ruas da Zona Sul, cinco da Cidade Alta, quatro na região Leste e oito na Zona Norte serão alcançadas.

Na ocasião da divulgação do Olho Vivo, o prefeito Bruno Siqueira e o comandante da 4ํㅡ Região de Polícia Militar (RPM), coronel Ronaldo Nazareth, também apresentaram um pacote com mais seis ações integradas para a segurança, o qual será gerenciado por meio de uma parceria entre Prefeitura e PM: o programa Cidade, cidadania e segurança. Tal projeto estabelece como meta a união de esforços em prol da segurança pública, com consequente recuo dos registros de homicídio e aumento da sensação de segurança.

Entre as iniciativas propostas pela Cidade, cidadania e segurança destaca-se a criação da Rede Mediadora de Conflitos (que visa a restringir os casos de assassinatos e conflitos entre grupos rivais); do Conselho Municipal de Políticas Integradas sobre Drogas (Compid) (com foco na prevenção e repressão ao uso de entorpecentes e ao tráfico de drogas) e o fortalecimento do Programa Educacional de Resistência às Drogas e à Violência (Proerd). As medidas ainda preveem um curso de especialização em Segurança

(Cpec) por meio dos Centros de Prevenção à Criminalidade (CPCs), sedes de referência para as comunidades atendidas. Fonte: SEDS (Secretaria de Estado e Defesa Social)

85 Dados sobre Segurança e Criminalidade em Juiz de Fora e Minas Gerais: Disponível em:<http://www.cps.ufjf.br/anuarios/Anuario2012/index.html>, acessado em 25 abr. 2014. 
Pública e Cidade, a ser desenvolvido em parceria com a UFJF e destinado à qualificação de policiais militares e agentes públicos ${ }^{86}$ e a ampliação do programa Ambiente de paz, destinado a melhorias na infraestrutura de praças e vias.

Como se pode perceber, apesar de algumas promessas tendentes à prevenção, a menina dos olhos dos programas é a repressão. Da recusa quanto à percepção da insegurança social como produto da desregulamentação econômica e do recuo dos esquemas de proteção social investe-se na ampliação do poder punitivo como forma de resolução dos conflitos ${ }^{87}$.

Os referidos projetos, porém, parecem não ter levado em conta o fato de que o incremento dos sistemas de monitoramento e a efetiva apreensão em flagrante dos sujeitos envolvidos nas cenas de crime terá como consequência o aumento efetivo das apreensões e prisões provisórias. Tais prisões contribuirão para aumentar, ainda mais, a superlotação das instituições prisionais locais ${ }^{88}$, que já contam com grande excedente de presos, em sua maioria provisórios - ou seja, à espera de julgamento ${ }^{89}$. A superlotação das instituições locais vem sendo alvo de manifestações e críticas por parte da Defensoria Pública há vários anos, com destaque para a precariedade das condições de vida dos presos, violência e risco constante de rebeliões.

Sob o signo do perigosismo, o Olho vivo garantirá maior repressão, mas não contemplará as outras demandas sociais, sobretudo as medidas de prevenção à violência. Essa tática, como visto, vem sendo utilizada pelo poder público nos núcleos urbanos desde a Revolução Industrial no século XIX e, empírica e historicamente, vem demostrando seu insucesso ${ }^{90}$.

\footnotetext{
${ }^{86}$ Disponível em: <http://www.cps.ufj..br/centro-de-pesquisas-sociais-da-ufjf-sediara-laboratorio-de-estudossobre-violencia/>, acessado em 24 abr. 2014.

${ }^{87}$ Nascimento, M. L.; Rodrigues, R. C. (2012), "A convergência sócio/penal na produção e gestão da insegurança social”. In Batista, V. M. (Org.) (2012). Op. Cit. p. 197.

${ }^{88}$ De acordo com os dados relativos ao mês de abril de 2013 apresentados pelo GEOPRESÍDIOS (plataforma eletrônica desenvolvida pelo CNJ - Conselho Nacional de Justiça - para o acompanhamento da realidade prisional no Brasil) no CERESP (Centro de Remanejamento do Sistema Prisional) de Juiz de Fora, que tem capacidade para 332 detentos e que deveria funcionar como núcleo de acolhimento dos presos provisórios, há atualmente 849 homens presos, sendo 704 provisórios. Já na Penitenciária Ariosvaldo Campos Pires, cuja capacidade é de 258 homens e 138 mulheres, encontram-se 365 detentos do sexo masculino e 116 do sexo feminino, sendo que dos homens 121 está preso provisoriamente. $\mathrm{Na}$ Penitenciária José Edson Cavalieri, com capacidade para 366 presos, estão detidos 414 homens. O Hospital de Toxicômanos também tem a maioria dos pacientes composta de presos provisórios, perfazendo um total de 63 homens.

${ }^{89}$ A despeito dos projetos tendentes à capacitação profissional dos detentos atualmente desenvolvidos no sistema prisional de Juiz de Fora - os quais merecem nosso apoio e respeito - apenas um pequeno percentual é contemplado. Segundo os dados do CNJ, no sistema prisional de Juiz de Fora o número de presos estudando é de 5 a $15 \%$ e contingente que trabalha varia entre 10 a $20 \%$. Tais estatísticas nos obrigam a refletir sobre o poder que a prisão tem de reverter o quadro de seletividade e exclusão social.
}

${ }^{90}$ Wacqüant, Loïc (2003). Punir os pobres: a nova gestão da miséria nos Estados Unidos, Rio de Janeiro: 


\section{O recuo do Estado Social e o avanço do Estado Penal}

Em entrevista concedida à Revista Epos em 2012, o sociólogo francês Loïc Wacquant, procurou explicar como a desregulamentação econômica e as restrições ao bem-estar social foram estendidas ao controle punitivo da criminalidade ao longo do século XX. Professor da Universidade da Califórnia, Berkeley, e pesquisador no Centre Européen de Sociologie et de Sience Politique (Paris), Wacquant vem desenvolvendo importantes estudos acerca da marginalidade urbana, dominação étnico-racial, Estado Pena, entre outros. Sua obra "As prisões da miséria" está entre as mais destacadas sobre o tema na atualidade.

Conforme dito à Epos, ao longo da referida obra, o autor procura refletir sobre as políticas de tolerância zero e outras receitas estadunidenses milagrosas para o combate ao crime, como: a Teoria das Janelas Quebradas, toques de recolher para a juventude, penas mínimas obrigatórias, entre outras. Para o sociólogo, todas essas medidas fazem parte de uma política mais ampla que implica, grosso modo, em cobrir com um superávit punitivo o déficit social. Segundo Wacquant, bem-estar social e justiça criminal são duas modalidades de políticas públicas destinadas aos pobres e, por isso, devem, imperativamente, ser analisadas - e reformadas - em conjunto. Ambas as políticas combate à pobreza e combate à criminalidade - têm a mesma origem histórica que remonta o século XVI. Loïc as percebe, desde o seu nascedouro, como verdadeiras "estratégias para encurralar vagabundos destacados de seu ancoradouro social pela passagem do feudalismo para o capitalismo e para ensiná-los a ética do trabalho assalariado".

O professor destaca que nas duas frentes - políticas de bem-estar social e políticas penais - o público alvo é os mesmos em termos de classe, etnia, educação, moradia, histórico médico e familiar, exposição à violência e acesso a postos de trabalho. Em ambas as frentes o público é recrutado nos mesmos setores marginalizados da classe trabalhadora não qualificada. Em razão disso, Wacquant defende que não é possível seguir a política criminal sem computar as políticas sociais e vice-versa. Não é possível entender tendências à prática de crimes sem considerar as mudanças nas políticas de 
assistência social, habitação, adoção de programas públicos relacionados, que colocam as opções de vida para as populações mais suscetíveis à delinquência de rua (tanto como agente quanto como vítimas).

A opção pela política punitiva em detrimento das políticas sociais representaria uma fonte contínua de instabilidade social e uma máquina cultural poderosa que impacta decisivamente sobre a forma da cidade e o destino dos pobres. A par de tais considerações, o professor concluiu a entrevista e deixou um conselho aos estudiosos do tema: “- Unam-se. Vocês não têm nada a perder, exceto suas amarras conceituais".

\section{Considerações Finais}

No contexto neoliberal, como assinala Wacquant, a mecânica de poder que através da microfísica ${ }^{91}$ das instituições do Estado - articula políticas de segurança pública, econômicas e assistenciais, revelou um incremento sem precedentes quanto à policização dos programas sociais de assistência social. Como visto acima, para o autor, a articulação das preocupações com o controle e administração das categorias despossuídas mudou o formato da paisagem social e recriou o próprio Estado, o qual não mais faz o uso legítimo do monopólio da violência material ${ }^{92}$, mas também o da violência simbólica ${ }^{93}$.

O conceito de violência simbólica desenvolvido por Wacquant, a partir da obra do sociólogo francês Pierre Bourdieu, visa a explicar como a violência, obscurecida através de discursos e práticas legitimantes, vai sendo aos poucos naturalizada pela sociedade, e termina por já não ser percebida como violência. É esse mesmo mecanismo que faz com que fenômenos como a escalada da violência em Juiz de Fora não sejam percebidos de forma ampla. Os efeitos da naturalização das políticas repressivas, sem um contraponto crítico sobre os problemas sociais, são percebidos por Vera Malaguti Batista como uma espécie de adesão subjetiva à barbárie que, grosso modo, consiste numa crescente demanda coletiva por instrumentos de controle social cada vez mais ofensivos, que convive com "[...] a neutralidade técnica das governamentalidades sociológicas. Os efeitos estão por aí e doem: a expansão da prisão, sua teia ampliada de justiças alternativas,

\footnotetext{
${ }^{91}$ Foucault, M.(1979). A Microfísica do Poder, Rio de Janeiro: Graal.

${ }^{92}$ Weber, M. (2004). A ética protestante e o espírito do capitalismo, São Paulo: Companhia das Letras.

${ }^{93}$ Bourdieu, P. (2007). O Poder Simbólico, Rio de Janeiro: Bertrand Brasil.
} 
terapêuticas, restauradoras, a vigilância reticular, o controle a céu aberto, a transformação das periferias em campos [... $]^{\prime 94}$.

As estratégias seletivas de controle social que vêm arrasando os contingentes mais vulneráveis da sociedade fazem parte da história das sociedades modernas, a força empreendida por elas na atualidade, no entanto, é assustadoramente mais ampla, posto que os índices de encarceramento e outras formas de privação e liberdade com os mais diversos nomes alcançam níveis nunca antes percebidos na história da humanidade.

No Brasil, como alerta a Professora Vera Malaguti ao longo de suas obras e nos cursos de Criminologia na UERJ, a política de segurança pública, sob o signo do medo, vai - através de alianças com as agências econômicas - amalgamando outros setores, até mesmo a Academia e forças políticas da administração da Justiça, que deveriam ser um núcleo de resistência.

Pensar as políticas destinadas à superação das tensões sociais que ora se descortinam no município de Juiz de Fora, como pôde ser evidenciado acima, implica, portanto, em considerar todos os aspectos envolvidos. Optar por políticas excludentes, meramente repressivas e punitivas, somente reforça o cenário de vulneralibilidade social e tende a aumentar, ainda mais, os quadros de violência. Para oferecer um contraponto efetivamente positivo e preventivo é necessário que estejamos dispostos a limpar as lentes com as quais enxergamos esta realidade para que a partir daí, oxalá, possamos construir melhores paisagens.

\section{Referências}

Abreu, C. S. (2009). Favela e remoção em Juiz de Fora: um estudo sobre a Vila da Prata. Dissertação (Mestrado) - Universidade Federal de Juiz de Fora, Juiz de Fora.

. (2010). "Favelas em Juiz de Fora: a ocultação do fenômeno". In Libertas, Juiz de Fora, v.4, n.1, p. $146-170$.

Abreu, M. de A. (1994). "Reconstruindo uma história esquecida: origem e expansão inicial das favelas do Rio de Janeiro". In Revista Espaço e Debates, São Paulo, n. 5, p.34-46.

\footnotetext{
${ }^{94}$ Batista, V.M. (2012). "Adesão subjetiva à barbárie". In Batista, V.M. (Org.) (2012). Op. Cit., p. 309-310.
} 
Almeida, F. A. (2011). "Os Movimentos Populares em Juiz de Fora nos Anos 80". In Anais da XXVIII Semana de História da Universidade Federal de Juiz de Fora, Juiz de Fora: UFJF. Disponível: <http://www.ufjf.br/semanadehistoria/files/2011/08/Anais-da-XXVIIISemana-de-Hist\%C3\%B3ria-2011.pdf>. Acesso em: 24 abr. 2014.

Almeida, R. (2005). "Planejamento Urbano em Juiz de Fora: Reflexões Históricas". In Anais do I Colóquio de História Econômica e Social da Universidade Federal de Juiz de Fora. Disponível em: <http://www.ufjf.br/lahes/files/2010/03/c1-a59.pdf>. Acesso em: 24 abr. 2014.

Andrade, S. M. B. V. (1987). Classe operária em Juiz de Fora: uma história de lutas (1912-1924), Juiz de Fora: Ed.UFJF.

Anitua, G. I. (2008). História dos pensamentos criminológicos, Rio de Janeiro: Revan.

Araujo, L. S. (2005). "Cidade e Cidadania: a experiência dos trabalhadores em Juiz de Fora (1900-1918)". In Anais do I Colóquio de História Econômica e Social - UFJF. Disponível em: <http://www.ufjf.br/lahes/files/2010/03/c1-a45.pdf>. Acesso em: 23 abr. 2014.

Barata, A. (2002). Criminologia crítica e crítica do direito penal: introdução à sociologia do direito penal. 3. ed., Rio de Janeiro: Revan.

Batista, C. S. (2012). A opinião pública e os escravos em um núcleo urbano da Zona da Mata mineira, Juiz de Fora 1870 - 1888. Disponível em: $<$ http://web.cedeplar.ufmg.br/cedeplar/seminarios/ecn/ecnmineira/2012/arquivos/A\%20opini\%C3\%A30\%20p\%C3\%BAblica\%20e\%20os\%20escravo s\%20em\%20um\%20n\%C3\%BAcleo\%20urbano.pdf>. Acesso em: 23 abr. 2014.

Batista, N. (1996). Introdução crítica ao Direito Penal brasileiro, Rio de Janeiro: Revan. (2006). "História da programação criminalizante no Brasil”. In Zaffaroni, R.E. et al. (2006). Direito penal brasileiro, Rio de Janeiro: Revan.

Batista, V.M. (2003). O medo na cidade do Rio de Janeiro. Dois tempos de uma história, Rio de Janeiro: Revan.

. (2011). Introdução crítica à criminologia brasileira, Rio de Janeiro: Revan.

(2012). "Adesão subjetiva à barbárie". In Batista, V.M. (Org.) (2012). Loïc Wacquant e a questão criminal no capitalismo neoliberal, Rio de Janeiro: Revan, p. 309310.

(Org.) (2012). Loïc Wacquant e a questão criminal no capitalismo neoliberal, Rio de Janeiro: Revan.

Bastos, W. de L. (1987). "Do Caminho Novo dos Campos Gerais à estrada de rodagem União e Indústria e estrada de ferro D. Pedro II". In: Bastos, W. de L. (1987) et al. História 
econômica de Juiz de Fora (subsídios), Juiz de Fora: Instituto Histórico e Geográfico. p. 930 .

Borges, C. M. (Org.) (2000). Solidariedades e conflitos: histórias de vidas e trajetórias de grupos em Juiz de Fora, Juiz de Fora: Ed. UFJF.

Borges, I. C. M. M. (2005). "É proibido negociar com ciganos e suspeitos..." - O trabalho na Manchester Mineira. In Anais do I Colóquio de História Econômica e Social - UFJF. Disponível em: <http://www.ufjf.br/lahes/files/2010/03/c1-a30.pdf>. Acesso em: 23 abr. 2014.

Botti, C. A. H. et al. (1994). Companhia Mineira de Eletricidade, Juiz de Fora: Companhia Energética de Minas Gerais, Centro de Pesquisas Sociais, UFJF.

Bourdieu, P. (2007). A Distinção: crítica social do julgamento, São Paulo: EDUSP. (2007). O Poder Simbólico, Rio de Janeiro: Bertrand Brasil. (2003). A miséria do mundo, Petrópolis: Vozes.

Campos, A. (2005). Do quilombo à favela: a produção do -espaço criminalizadoll no Rio de Janeiro, Rio de Janeiro: Bertrand Brasil.

Carneiro, D. F. (2011). O Tribunal e seus casos: um perfil da Justiça e dos Processos Criminais de Calúnia e Injúria em Minas Gerais (JUIZ DE FORA - 1854/1941), Rio de Janeiro:

TJRJ.

Disponível

em: <http://www.tjrs.jus.br/export/poder_judiciario/historia/memorial_do_poder_judiciario/mem orial_judiciario_gaucho/revista_justica_e_historia/issn_1677-

065x/v9n17n18/O_TRIBUNAL.pdf>. Acesso em: 23 abr. 2014.

Chaves, T. S. (2011). "Estudo de caso - a cidade de Juiz de Fora MG - sua centralidade e problemas sócio-econômicos". In Rev. GEOMAE, Campo Mourão, v.2, n. esp.1, p.155 170.

Christo, M. C. V. (1994). Europa dos pobres: Juiz de Fora na Belle Époque Mineira, Juiz de Fora, MG: EDUFJF.

Coimbra, C.; Scheinvar, E. (2012). "Subjetividades punitivo-penais". In Batista, V. M. (Org.) (2012). Loïc Wacquant e a questão criminal no capitalismo neoliberal, Rio de Janeiro: Revan, p. 61-70.

Dutra, E. F. (1998). Caminhos operários nas Minas Gerais, São Paulo: Hucitec.

Esteves, A. (2008). Álbum do Município de Juiz de Fora, Juiz de Fora: FUNALFA.

Fazollato, D. (2001). Juiz de Fora: imagens do passado, Juiz de Fora: Funalfa. 
Foucault, M. (1979). A Microfísica do Poder, Rio de Janeiro: Graal. . (1987). Vigiar e punir: nascimento da prisão, Petrópolis: Vozes. . (2008). Território, segurança e população, São Paulo: Martins Fontes.

Freitas, E. L. H. de. (2004). Como qualificar conjuntos habitacionais populares, Brasília: Caixa Econômica Federal. Dissertação (Mestrado) - Faculdade de Arquitetura e Urbanismo da Puc-Campinas, Campinas.

Goodwin Jr., J. W.(1986). A "Princeza de Minas": a construção de uma identidade pelas elites juizforanas. 1850-1888. Dissertação (Mestrado) - Programa de Pós-Graduação em História da UFMF, Belo Horizonte: FAFICH / UFMG.

Guimarães, E. S. (2006). Violência entre parceiros de cativeiro: Juiz de Fora, segunda metade do século XIX, São Paulo: Annablume.

Jacobs, J. (2000). Morte e Vida de Grandes Cidades, São Paulo: Martins Fontes.

Juiz de Fora. Prefeitura Municipal (2004). Plano Diretor de Desenvolvimento Urbano de Juiz de Fora, Juiz de Fora (MG): FUNALFA Edições.

Matos, L. P. (2008). "Entre vozes e discursos: a análise da documentação criminal para o estudo da imigração em Juiz de Fora no final do século XIX". In Anais do /I Colóquio do LAHES. Disponível em: <http://www.lahes.ufjf.br>. Acesso em: 23 abr. 2014.

Musse, C. F. (2006). Imprensa, cultura e imaginário urbano: exercício de memória sobre os anos 60/70 em Juiz de Fora. Tese (Doutorado) - Programa de Pós-Graduação em Comunicação da Escola de Comunicação, UFRJ.

Nascimento, M. L.; Rodrigues, R. C. (2012), "A convergência sócio/penal na produção e gestão da insegurança social”. In Batista, V. M. (Org.) (2012). Loïc Wacquant e a questão criminal no capitalismo neoliberal, Rio de Janeiro: Revan, p. 197-203.

Oliveira, F. A. (2005). "A cadeia pública e o sustento dos presos pobres em Juiz de Fora, 1855-1889". In Anais do I Colóquio do LAHES. Disponível em: <http://www.ufjf.br/lahes/files/2010/03/c1-a23.pdf>. Acesso em: 23 abr. 2014.

Oliveira, M. R. de. (1991). Imigração e industrialização: os alemães e os italianos em Juiz de Fora (1854-1920). Dissertação (Mestrado) - Programa de Pós-Graduação em história, Univ

Paula, M. C. de S. (1976). As vicissitudes da industrialização periférica: o caso de Juiz de Fora (1930-1970). Dissertação (Mestrado) - DCP, UFMG. 
Paula, Z. A. de (2006). E do caminho novo das Minas dos Matos Gerais emerge a 'Manchester Mineira' que se transformou num "bau de ossos": história de Juiz de Fora: da vanguarda de Minas Gerais a "industrialização periférica. Tese (Doutorado) - Programa de Pós-Graduação em História Econômica, Campinas: UNICAMP. Disponível em:<http://www.bibliotecadigital.unicamp.br/document/?code=vtls000378898>. Acesso em: 24 abr. 2014.

Rauter, C. (2003). Criminologia e Subjetividade no Brasil, Rio de Janeiro: Revan.

Romagnoli, A. (s.d.). O programa "minha casa, minha vida": continuidades, inovações e retrocessos. São Paulo: UNESP. Disponível: $<$ http://www.fclar.unesp.br/Home/Departamentos/AdministracaoPublica/RevistaTemasdeA dministracaoPublica/artigoalexandreromagnoli.pdf >. Acesso em: 25 abr. 2014.

Santos, M. (2001). Por uma outra globalização: do pensamento único à consciência universal. 6. ed., Rio de Janeiro: Record.

Silva-Sanches, J. M. (2002). A expansão do direito penal: aspectos da política criminal nas sociedades pós-industriais, São Paulo: Revista dos Tribunais.

Souza, M. (2012). "É Hora de Mudar: A política industrial de Getulio Vargas e Lula". In Anais da XXIX Semana de História da Universidade Federal de Juiz de Fora, Juiz de Fora: UFJF, p. 547-561. Disponível em: <http://www.ufjf.br/semanadehistoria/files/2010/02/Anais-da-Semana-de-Hist\%C3\%B3ria20122.pdf>. Acesso em: 24 abr. 2014.

Souza, M. A. A. (2012), "Uso do território e sistema de justiça no Brasil". In Batista, V.M. (Org.) (2012). Loïc Wacquant e a questão penal no capitalismo neoliberal, Rio de Janeiro: Revan, p. 131-154.

Suzigan, W.; Furtado, J. (2006). "Política Industrial e Desenvolvimento". In Revista de Economia Política, v. 26, n. 2 (102), p. 163-185, abr./jun.

Tavares, G. (Org.) (2006). Atlas Social - Juiz de Fora, Juiz de Fora: Prefeitura de Juiz de Fora.

Tasca, L. (2010). As contradições e complementaridades nas leis urbanas de Juiz de Fora: dos planos aos projetos de intervenção. Tese (Doutorado)-Universidade Federal do Rio de Janeiro.

Toledo, J. A. C. et al. (2013). "A influência da mídia na estigmatização de jovens e lugares da cidade". In Anais do XIII Simpósio de Geografia Urbana, Rio de Janeiro: UERJ. Disponível em: <http://www.simpurb2013.com.br/wpcontent/uploads/2013/11/GT14_juliana.pdf>. Acesso em: 24 abr. 2014.

Wacqüant, Loïc (2011). Forjando o Estado Neoliberal: trabalho social, regime prisional e insegurança social, Rio de Janeiro: no prelo. 
(2003). Punir os pobres: a nova gestão da miséria nos Estados Unidos, Rio de Janeiro: Revan.

Weber, M. (2004). A ética protestante e o espírito do capitalismo, São Paulo: Companhia das Letras.

Zaffaroni, E.R. (2007). O inimigo no direito penal, Rio de Janeiro: Revan. 